\title{
Evaluation of notional loads magnitude to three calibration concentric braced frames subjected to seismic loads in Indonesia
}

\author{
Purnomo Heru ${ }^{1}$, Orientilize Mulia ${ }^{1, *}$, A Rahim Sjahril ${ }^{1}$, and Firdaus A Zaki ${ }^{1}$ \\ ${ }^{1}$ Department of Civil Engineering, Universitas Indonesia, Depok, Indonesia
}

\begin{abstract}
The changing of SNI 03-1729 from 2002 to 2015 which refer to AISC 2010 change the method of steel stability analysis from effective length method (ELM) to direct analysis method (DAM). DAM use second order elastic analysis, accommodate strength reduction, geometric imperfection presented as notional load, and take buckling factor $(\mathrm{K})$ equal to 1 . Numerical study has been conducted to find out the appropriate magnitude of notional loads on concentric braced frame subjected to seismic load in Indonesia. Experimental results from three different calibration frames from previous research were used as reference. The frames consisted of 1-story, 3-stories, and 5-stories were reanalyzed by using SAP software with four different methods: ELM first order elastic analysis, ELM second order elastic analysis, and DAM with different notional loads coefficient as 0.002 and 0.003 . Seismic loads according SNI 1726:2012 in three seismic regions were considered.
\end{abstract}

\section{Introduction}

The rapid change of constructions building leads to complex structural analysis. A long time ago structural analysis was conducted manually, and hence some simplification was taken. During the time, research has been carried out to get a better understanding of structural behavior, and the results have been accommodated into design code. The development of finite element software and computer processor speed up the research conducted. Hence, the design code should be updated several times to adapt to the new invention in structural analysis and design.

Indonesia is late in accommodating the change of structural steel building design code which was referred to AISC 360-10. SNI 03-1729-2015 [1], design code for steel structural building in Indonesia is a revision of the former code of SNI 03-1729-2002 [2]. The 2015 code is a translation version of AISC 360-2010. However, AISC has been updated several times, and AISC 2010 is a correction of AISC 2005. One of significant change from AISC 2005 to 2010 is steel structure stability analysis. AISC 2005 has effective length method (ELM) as the main method as mentioned in Chapter C: Design for Stability [3] and AICS 2010 has direct analysis method (DAM) as the main method as mention in Chapter C: Design for Stability [4]. DAM was introduced in AISC 2005 as an alternative to steel

*Corresponding author: mulia@eng.ui.ac.id 
stability design. Until 2015, ELM is the main method for steel structural stability in Indonesia according to SNI 2002. After 2015, ELM is only an alternative method replaced by DAM. ELM can be used if the ratio of maximum second-order drift to maximum firstorder drift (both determined for LRFD load combinations or 1.6 times ASD load combinations) in all stories is equal to or less than 1.5 [4].

To estimate the capacity of individual steel columns, ELM, and DAM use column interaction equations [5]. ELM approximate the P-delta effect by using the amplification factor, and the value of effective length factor $(\mathrm{K})$ is estimated based on relative rigidity between girder and column. DAM take advantage of computer and software development, where P-delta effect can be directly calculated in the analysis and the $\mathrm{K}$ value is set as 1 . Also, DAM accommodates geometric imperfection and strength reduction during analysis. The geometric imperfection of $1 / 500 \mathrm{~L}$ is represented as notional load as 0.002 of gravity load. AISC 2010 on section C.2.2 allow adjusting the notional load coefficient proportionally based on a nominal initial story out-of-plumbness ratio.

Some research has been done to see the effect of ELM and DAM to structural steel design $[5,6]$. The results found that ELM has higher stress ratio on 1-storey with one bay steel structure [5]. Another test results of 1 story and three bays steel building confirmed that finding [6]. The study conducted on moment resisting frames, none of the studies use another structural system such as a concentrically braced frame. Also, there is no study concern about the magnitude of notional loads even though AISC permits to adjust the value.

Study to evaluate the magnitude of the notional load was carried out on a concentric steel braced frame. A comparison study of ELM and DAM is also performed by taking into account seismic load according to Indonesia seismic zone [7]. Concentrically braced frame (CBF) was chosen as an earthquake resistance building system. CBF gain their strength and their resistance to lateral forces and displacements primarily from the axial strength and stiffness of the bracing members. CBF system tends to be more economical than moment resisting-frames when material, fabrication and erection cost are considered [8]. The study is conducted using SAP software [9]. Calibration frame from previous research based on experimental results was chosen as referenced.

\section{Validation of numerical simulation}

As mentioned earlier, the numerical study was conducted using Finite Element (FE) software, SAP2000. To validate the model, calibrations were performed using experimental study conducted by other researchers. The concentrically braced frames consist of 1, 3 and 5 stories and hereafter, those are appointed as calibration frame 1, 3, and 5, respectively. The experimental results are named according to a researcher experimenting. They are Faggiano et al. [10] for one story, Yang et al. [11] for three stories, and Hosseini et al. [12] for five stories. The experimental set-up of three frames is modeled and reanalyzed using SAP. Results of experimental study and the SAP model are plotted together in the same graph in order to see how close the numerical simulation can represent the actual condition. After completing the validation stage, the next study based on numerical simulation can be carried out.

Fig. 1 shows the detail of three frames modeled in SAP. Geometrical features, materials, and boundary conditions are assumed according to the experimental. According to the experimental set-up, all frames are loaded horizontally, and its self-weight represented the vertical load. Different load patterns are applied to each frame. Horizontal loads are applied only on top of calibration 1 and 5. Meanwhile, horizontal loads are applied on each level of calibration three where the shape of the force pattern over the height of the structure was based on first mode invariant lateral force. Non-linearity in geometry and material were 
taken into account to represent the non-linear inelastic analysis as occurred on the experimental test.

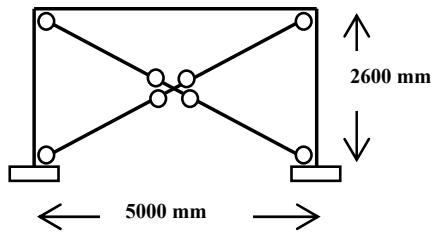

Beam : H 250x125x6x9

Column : H $175 \times 175 \times 7.5 \times 11$

Brace : H $100 \times 50 \times 5 \times 7$

○ Moment release

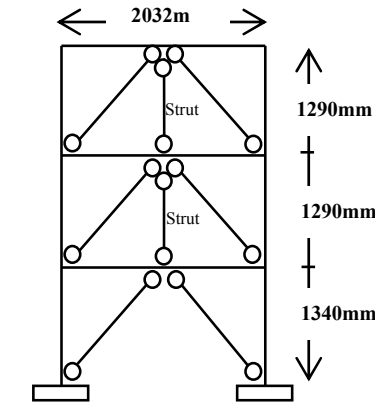

Column : S $4 \times 9.5$

Beam : S $3 \times 7.5(1)$; S $5 \times 10$ (2); S $5 \times 5.7$ (3)

Beam : $3 \times 7.5(1$

Strut : HSS $1.25 \times 1.25 \times 3 / 16(2)$;

HSS $2 \times 2 \times 3 / 16(3)$

Brace : HSS $2 \times 2 \times 1 / 8(1,2)$; HSS $3 \times 3 \times 3 / 16(3)$

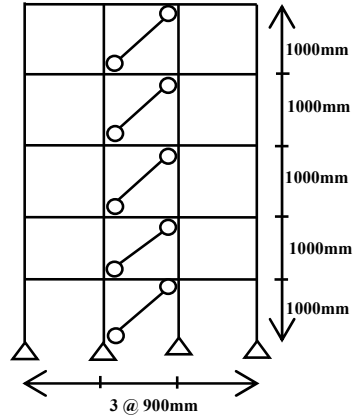

Column : IPE 180

Beam : IPE 140

Brace : PL $4 \times 1.2$

Fig. 1. Calibration Frame 1, 3, and 5.

Numerical model also included geometric imperfection. Calibration frame one has initial imperfection as L/800 for each column. Expected yield stress and ultimate stress (Fye and Fue) are varied for each member. For column, the value is 253 and $423 \mathrm{MPa}$ for Fye and Fue, respectively. Then, the value of Fye and Fue for beam are 275 and $408 \mathrm{MPa}$, and brace are 293 and $461 \mathrm{MPa}$, respectively.

Meanwhile, calibration frame 3 has initial imperfection as L/2000 and the material used for column and beam are ASTM A572 Grade 50 whereas brace is ASTM A500 Grade B. Moreover, calibration frame five was modeled with initial imperfection as L/500 with different material properties on beam-column and brace. Yield stress (Fy) and ultimate stress $(\mathrm{Fu})$ of beam and column are $180 \mathrm{MPa}$ and $300 \mathrm{MPa}$, respectively whereas brace has $235 \mathrm{MPa}$ and $360 \mathrm{MPa}$. Push over-analysis was carried to represent step by step of load increment during the test, and plastic hinged at brace edges were assigned. P-delta with large displacement analysis was carried out as a representation of geometric non-linearity.

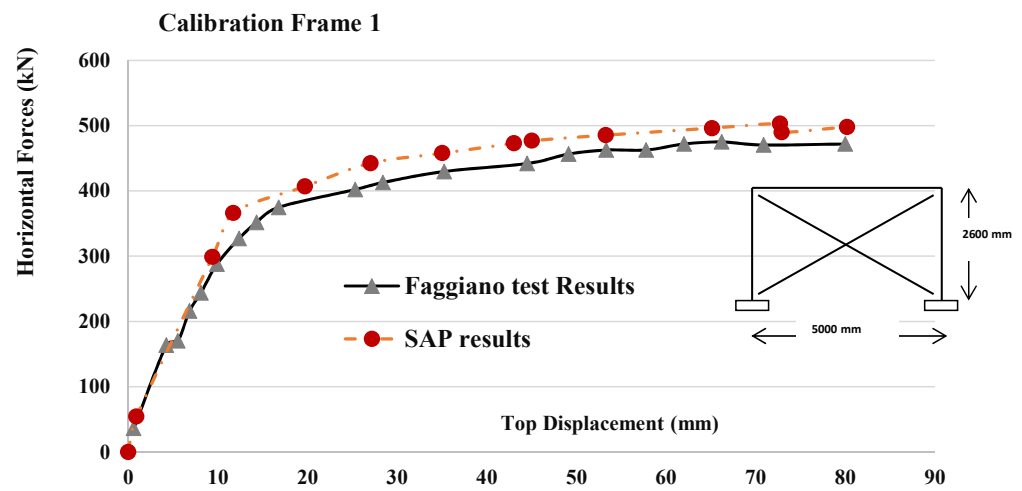

Fig. 2. Validation results of calibration Frame 1.

Fig. 2-4 shows a comparison of the load-deflection curve between the SAP model and test results of all calibration frames. As can be seen in Fig. 2-4, close results are found between experimental and numerical simulation. Numerical simulation detects that the 
plastic hinge appears for the first time on bracing according to the failure mode of experimental test. There are some gaps between numerical and test simulation graph as shown in Fig. 4 where the initial stiffness of the numerical model is higher than the experiment. However, the ultimate forces detected on the numerical model $(13.38 \mathrm{kN})$ is close to experimental results (12.3) with a difference of $8 \%$. In general, it can be concluded that the numerical simulation using SAP software can simulate the experimental set-up of three CBFs. Hence, numerical simulation is considered valid and can be used for further study. Hereafter, results of numerical simulation from three calibration frames can be assumed as advanced analysis since it can simulate the experimental test. Advanced analysis is used as a reference to compare ELM and DAM discussed in section 3. Advanced analysis can be defined as non-linear inelastic analysis when both geometric and material non-linearity are considered in the analysis.

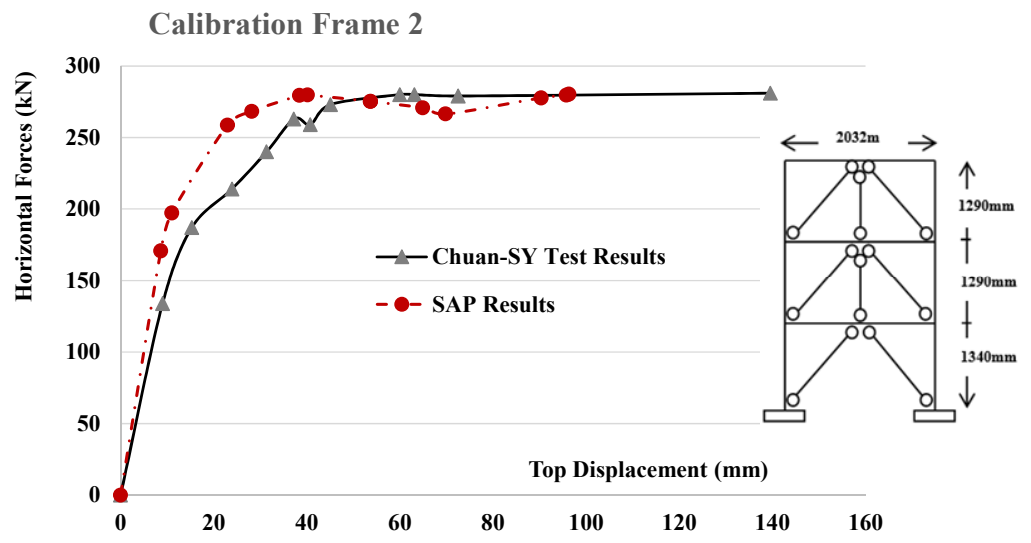

Fig. 3. Validation results of calibration Frame 3.

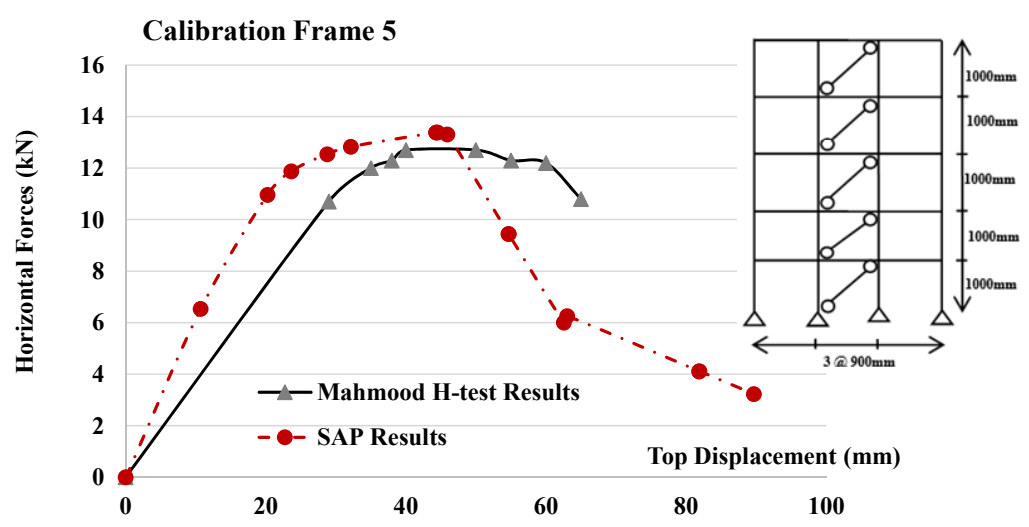

Fig. 4. Validation results of calibration Frame 5.

\section{Comparison study of ELM and DAM on three CBFs}

This section is discussed about comparison study between the use of ELM and DAM for steel stability analysis according to AISC 2010 and Indonesian design code of steel structure. Before 2015, ELM is the only method adopted in SNI 03-1729-2002. The updating of steel design code to SNI 2015 change the main method from ELM to DAM. However, ELM still can be used as an alternative method. Unlike SNI 2002 where only 
ELM with the first-order elastic analysis is introduced, SNI 2015 which refer to AISC 2010 allow ELM second-order elastic analysis. Based on Appendix 8 AISC 2010 [2], the P-delta effect is calculated based on the amplification factor for ELM first-order elastic analysis. ELM can also be analyzed as a second order analysis if the P-delta effect is included in the analysis. Detail requirement about DAM and ELM in AISC 360-10 can be found in Chapter $\mathrm{C}$ and Appendix 8, respectively. Besides imperfection, stiffness reduction as $20 \%$ from the initial condition is also considered for DAM, except for displacement calculation.

Comparative study about ELM and DAM have been done by other researchers [5-6], but none concern about notional loads and different approach of ELM for P-delta effect. Two different approaches of ELM analyzed calibration frame. First, the P-delta effect for ELM first order is calculated by using moment amplification factor, whereas ELM second-order analysis is similar to DAM where P-delta effect is directly calculated during the analysis. The initial imperfection of column presented as a notional load are applied as a lateral load for DAM. AISC allows adjusting the notional load factor instead of 0.002 . Two different notional loads coefficient as 0.002 and 0.003 was also performed. Hence, four stability methods named as ELM first order, ELM second order, DAM_0.002, and DAM_0.003 are compared to each other. The study is limited to three calibration frames as presented on Fig. 1.

The objective of this study is to see the effect of the different value of notional load applied to represent the column plumbness. Another objective is to see how effective the amplification moment factor can represent the P-delta effect on ELM analysis. Pushover analysis was performed to three calibration frames with similar lateral load patterns with the experimental test. Calibration frame 5 used adjusted static equivalent (seismic forces) pattern according to equation 1-2 which is based on ASCE 7-16 [13] using linear elastic seismic analysis. Advanced analysis based on valid numerical models discussed in section 1 is chosen as a benchmark. Seismic load equation:

$$
\begin{aligned}
& F_{x}=C_{v x} V \\
& V=C_{s .} W
\end{aligned}
$$

where $C_{v x}$ : Distribution factor for each floor, $C_{s}$ : Seismic response factor, $W$ : Total effective weight of structure, $F_{x}$ : Seismic load for X-story, $V$ : Base shear of structure.

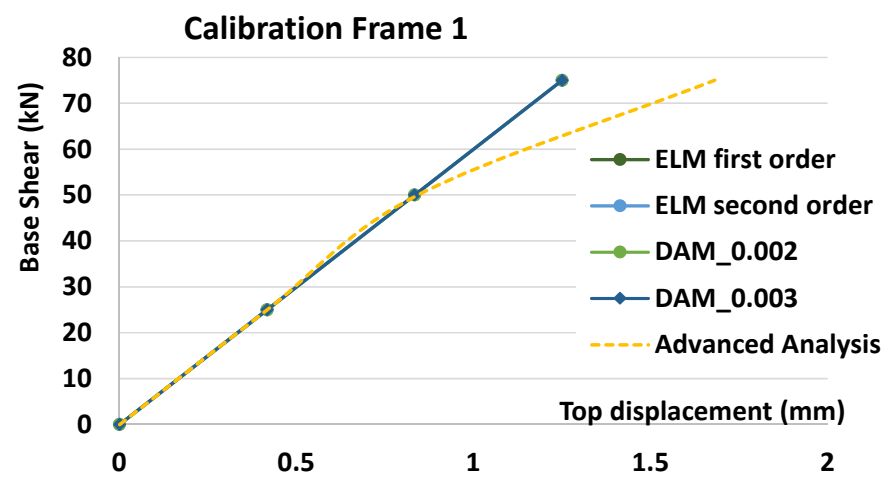

Fig. 5. Comparison results of calibration Frame 1.

Fig. 5-7 shows the study results which are plotted on base shear versus lateral displacement graph. Similar results are found on three calibration frames where the graphs of four methods are closed each other. The results of base shear and top displacement have the same value for all methods, except advanced analysis. The behavior of the structure is similar during the linear phase. For advanced analysis, the graph change from linear to non- 
linear after the plastic hinge appear on bracing which lead to structural stiffness reduction. Based on Fig. 5-7 it can be concluded that there is no significant change between ELM first order and second order analysis. A similar result is also found on the notional load that the change of the notional load coefficient from 0.002 to 0.003 does not affect the structural response of concentrically braced frames.

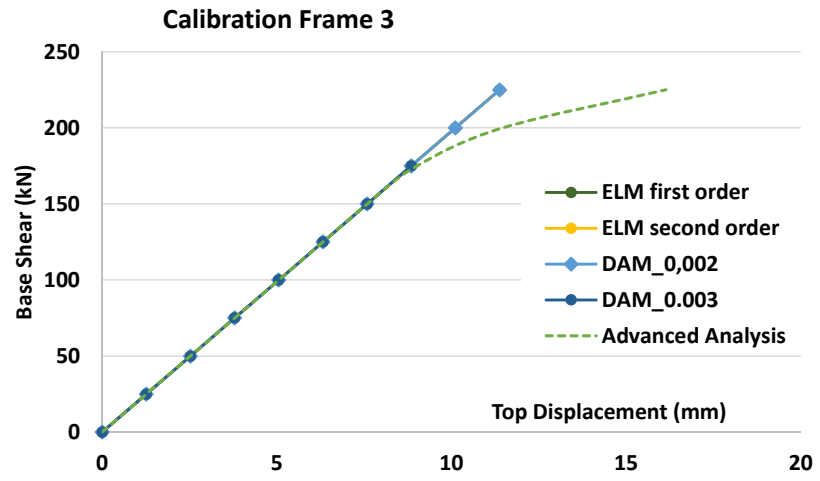

Fig. 6. Comparison results of calibration Frame 3.

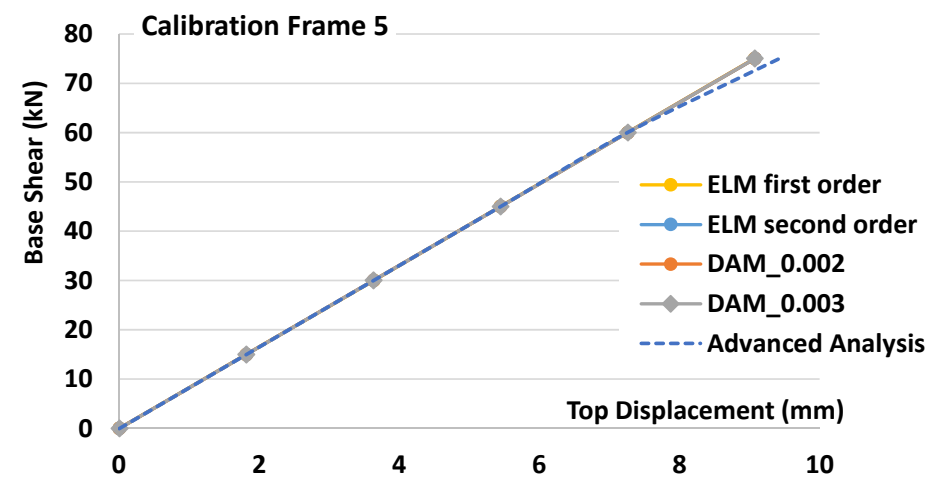

Fig. 7. Comparison results of calibration Frame 5.

\section{Study of concentric braced frames subjected to Indonesia seismic load}

As discussed earlier, similar behavior of concentrically braced frames presented on the load-displacement curve is found when ELM or DAM are used as structural stability. Similar results are also found when the notional load coefficient is changed from 0.002 and 0.003 . Further study is carried out to investigate those effect to PM ratio of all structures. The frames were simulated in 3 different seismic zones in Indonesia, the lightest, medium and the strongest seismic load which are Samarinda, Jakarta, and Padang, respectively. Different soil types are also considered according to Indonesia Seismic Design Code, SNI 1726-2012 [14] where the symbol for hard, medium and soft soil are SC, SD, and SE, respectively.

Referring to experimental test as mentioned earlier, only dead load and the horizontal load applied on the structure. In this study, horizontal loads only consist of notional load and earthquake load. Therefore, load combinations for dead load (D), notional dead load (ND), and earthquake (E) according to ASCE [9] are as follow: (C1) 1.4D + 1.4ND, (C2) 
Table 1. PM Interaction of calibration frame 1.

\begin{tabular}{|c|c|c|c|c|c|c|c|}
\hline \multirow[b]{2}{*}{$\begin{array}{c}\text { Soil } \\
\text { Types }\end{array}$} & \multirow[b]{2}{*}{$\begin{array}{c}\text { Seismic } \\
\text { zones }\end{array}$} & \multirow{2}{*}{$\begin{array}{c}\text { Earthqua } \\
\text { ke Load } \\
(\mathbf{k N})\end{array}$} & \multicolumn{5}{|c|}{ PM interaction } \\
\hline & & & $\begin{array}{c}\text { ELM } \\
\text { 1st } \\
\text { Order }\end{array}$ & $\begin{array}{c}\text { ELM } \\
\text { 2nd order }\end{array}$ & $\begin{array}{r}\text { DAM } \\
-0.002\end{array}$ & $\begin{array}{r}\text { DAM } \\
-0.003\end{array}$ & $\begin{array}{c}\text { Advanced } \\
\text { Analysis }\end{array}$ \\
\hline \multirow{3}{*}{$\mathrm{SC}$} & Samarinda & 4.015 & 0.00946 & 0.00947 & 0.00946 & 0.00946 & 0.00946 \\
\hline & Jakarta & 23.284 & 0.02119 & 0.02119 & 0.02121 & 0.02123 & 0.02120 \\
\hline & Padang & 46.634 & 0.03788 & 0.03788 & 0.03789 & 0.03791 & 0.03788 \\
\hline \multirow{3}{*}{ SD } & Samarinda & 5.354 & 0.01017 & 0.01017 & 0.01017 & 0.01017 & 0.01017 \\
\hline & Jakarta & 26.396 & 0.02342 & 0.02342 & 0.02344 & 0.02345 & 0.02342 \\
\hline & Padang & 46.634 & 0.03788 & 0.03788 & 0.03789 & 0.03791 & 0.03788 \\
\hline \multirow{3}{*}{$\mathrm{SE}$} & Samarinda & 8.365 & 0.01176 & 0.01176 & 0.01176 & 0.01176 & 0.01176 \\
\hline & Jakarta & 30.109 & 0.02607 & 0.02607 & 0.02609 & 0.02610 & 0.02607 \\
\hline & Padang & 41.987 & 0.03456 & 0.03456 & 0.03458 & 0.03459 & 0.03456 \\
\hline
\end{tabular}

Table 2. PM Interaction of calibration frame 3 .

\begin{tabular}{|c|c|c|c|c|c|c|c|}
\hline \multirow[b]{2}{*}{$\begin{array}{c}\text { Soil } \\
\text { Types }\end{array}$} & \multirow[b]{2}{*}{$\begin{array}{c}\text { Seismic } \\
\text { Zones }\end{array}$} & \multirow[b]{2}{*}{$\begin{array}{c}\text { Earthquake } \\
\text { Load }(k N)\end{array}$} & \multicolumn{5}{|c|}{ Stress ratio } \\
\hline & & & $\begin{array}{c}\text { ELM } \\
\text { 1st } \\
\text { Order }\end{array}$ & $\begin{array}{c}\text { ELM } \\
\text { 2nd order }\end{array}$ & $\begin{array}{r}\text { DAM } \\
-0.002\end{array}$ & $\begin{array}{r}\text { DAM } \\
-\mathbf{0 . 0 0 3}\end{array}$ & $\begin{array}{c}\text { Advanced } \\
\text { analysis }\end{array}$ \\
\hline \multirow{3}{*}{$\mathrm{SC}$} & Samarinda & 21.440 & 0.0564 & 0.0590 & 0.0591 & 0.0591 & 0.0592 \\
\hline & Jakarta & 124.352 & 0.3296 & 0.3296 & 0.3297 & 0.3297 & 0.3299 \\
\hline & Padang & 249.052 & 0.7701 & 0.7747 & 0.7747 & 0.7747 & 0.8888 \\
\hline \multirow{3}{*}{ SD } & Samarinda & 28.596 & 0.0778 & 0.0778 & 0.0779 & 0.0779 & 0.0780 \\
\hline & Jakarta & 140.968 & 0.3733 & 0.3733 & 0.3733 & 0.3734 & 0.3736 \\
\hline & Padang & 249.052 & 0.7701 & 0.7747 & 0.7747 & 0.7747 & 0.8888 \\
\hline \multirow{3}{*}{$\mathrm{SE}$} & Samarinda & 44.676 & 0.1175 & 0.1201 & 0.1202 & 0.1202 & 0.1203 \\
\hline & Jakarta & 160.800 & 0.4972 & 0.5020 & 0.5020 & 0.5021 & 0.5021 \\
\hline & Padang & 224.236 & 0.6934 & 0.6980 & 0.6980 & 0.6981 & 0.7724 \\
\hline
\end{tabular}

$1.2 \mathrm{D}+1.0 \mathrm{E}$, and (C3) $0.9 \mathrm{D}+1.0 \mathrm{E}$. Among the three load combinations, C2 produces the highest PM interaction. Since all calibration frames have the same results, hereafter, only load combination $\mathrm{C} 2$ is used for seismic simulation. The results are presented on PM interaction where the formula is determined based on the ultimate load of axial and flexural compared to its every nominal capacity as follow: 
For ratio of $\mathrm{P}_{\mathrm{u}} / \phi \mathrm{P}_{\mathrm{n}} \geq 0.2$

For ratio of $\mathrm{P}_{\mathrm{u}} / \phi \mathrm{P}_{\mathrm{n}} \geq 0.2$
PM interaction : $\mathrm{P}_{\mathrm{u}} / \phi \mathrm{P}_{\mathrm{n}}+8 \mathrm{M}_{\mathrm{u}} /\left(9 \phi \mathrm{P}_{\mathrm{n}}\right) \leq 1$

PM interaction: $\mathrm{P}_{\mathrm{u}} /\left(2 \phi \mathrm{P}_{\mathrm{n}}\right)+\mathrm{M}_{\mathrm{u}} / \phi \mathrm{P}_{\mathrm{n}} \leq 1$

Table 3. PM Interaction of calibration frame 5.

\begin{tabular}{|c|c|c|c|c|c|c|c|}
\hline \multirow{2}{*}{$\begin{array}{l}\text { Soil } \\
\text { types }\end{array}$} & \multirow{2}{*}{$\begin{array}{c}\text { Seismic } \\
\text { zones }\end{array}$} & \multirow{2}{*}{$\begin{array}{c}\text { Earthquake } \\
\text { load (kN) }\end{array}$} & \multicolumn{5}{|c|}{ PM interaction } \\
\hline & & & $\begin{array}{c}\text { ELM } \\
\text { 1st Order }\end{array}$ & $\begin{array}{c}\text { ELM } \\
\text { 2nd order }\end{array}$ & $\begin{array}{r}\text { DAM } \\
-0.002\end{array}$ & $\begin{array}{c}\text { DAM } \\
\text { _0.003 }\end{array}$ & $\begin{array}{c}\text { Advanced } \\
\text { analysis }\end{array}$ \\
\hline \multirow{3}{*}{$\mathrm{SC}$} & Samarinda & 7.887 & 0.0564 & 0.0590 & 0.0591 & 0.0591 & 0.0592 \\
\hline & Jakarta & 45.743 & 0.3296 & 0.3296 & 0.3297 & 0.3297 & 0.3299 \\
\hline & Padang & 91.615 & 0.7701 & 0.7747 & 0.7747 & 0.7747 & 0.8888 \\
\hline \multirow{3}{*}{ SD } & Samarinda & 10.519 & 0.0778 & 0.0778 & 0.0779 & 0.0779 & 0.0780 \\
\hline & Jakarta & 51.856 & 0.3733 & 0.3733 & 0.3733 & 0.3734 & 0.3736 \\
\hline & Padang & 91.615 & 0.7701 & 0.7747 & 0.7747 & 0.7747 & 0.8888 \\
\hline \multirow[t]{3}{*}{ SE } & Samarinda & 16.434 & 0.1175 & 0.1201 & 0.1202 & 0.1202 & 0.1203 \\
\hline & Jakarta & 59.151 & 0.4972 & 0.5020 & 0.5020 & 0.5021 & 0.5021 \\
\hline & Padang & 82.486 & 0.6934 & 0.6980 & 0.6980 & 0.6981 & 0.7724 \\
\hline
\end{tabular}

Table 1-3 shows the value of PM interaction results on three calibration frames. As can be seen, PM interaction of each method is only slightly different. Calibration frame one which only consists of one-story has almost similar PM interaction for all methods at all seismic zone. Three and five stories CBFs shows except ELM first order, and the other three methods have similar results as can be seen in Table 2 and 3. However, in general, it can be said that different notional load coefficient does not much affect PM ratio. A similar fact is found when comparing ELM first order and second order analysis, except at Padang zone on calibration frame 3 and 5. It is also found that PM ratio of all calibration frames is below the allowable value. Hence, it can be concluded that the concentrically braced frame meets design criteria when using ELM or DAM as steel stability in three seismic zones and three different soil conditions in Indonesia. Also, ELM first order, ELM second order, and DAM can be used as steel stability analysis for the concentrically braced frame with the low story.

\section{Conclusions}

Numerical simulation with SAP software is capable of simulating the experimental test of three concentric steel braced frames on three different stories. It is proved by closer graph between experiment and SAP results on calibration frame 1, 3, and 5. The effect of different methods of steel stability analysis, ELM and DAM, to those calibration frames according to AISC 2010 is not significant as can be seen from lateral force versus displacement curve. The finding is confirmed by PM interaction results when a seismic load loads the frames according to Indonesian design code. Even though AISC allows to use different notional load coefficient other than 0.002, stability analysis using DAM with 
notional load coefficient as 0.003 has similar results with DAM_0.002. Further study should be conducted to the higher structure or other steel structural building system.

This works is supported by Hibah PITTA 2018 funded by DRPM Universitas Indonesia No. 2451/UN2.R3.1/ HKP.05.00/2018.

\section{References}

1. Standar Nasional Indonesia, Spesifikasi untuk Bangunan Gedung Baja Struktural SNI 1729-2015 (Badan Standardisasi Nasional, Jakarta, 2015)

2. Standar Nasional Indonesia, Tata Cara Perencanaan Struktur Baja untuk Bangunan Gedung SNI 03-1729-2002 (Badan Standardisasi Nasional, Jakarta, 2002)

3. AISC, Specification for Structural Steel Buildings ANSI/AISC 360-05 (American Institute of Steel Construction, Chicago, 2005)

4. AISC, Specification for Structural Steel Buildings ANSI/AISC 360-10 (American Institute of Steel Construction, Chicago, 2010)

5. J. Prajzner, Evaluation of the effective length method and the direct analysis method for the design of steel columns in frame structures (University of Maryland, Maryland, 2006)

6. A.E. Surovek, R.D. Ziemian, Structure Congress 2005 (2005)

7. R. Putra, J. Kiyono, Y. Ono, H. Parajuli, J. of Natural Disaster Sci. 33, 2 (2012)

8. AISC, Seismic Design Manual ANSI/AISC 360-06 (American Institute of Steel Construction, Chicago, 2006)

9. SAP2000, SAP2000 version 14 Analysis Reference Manual (Computers and Structures, Berkeley, 2012)

10. B. Faggiano, A. Formisano, G. Vaiano, F. Mazzolani, Key Eng. Materials 763 (2017)

11. C.S. Yang, R.T. Leon, R. DesRoches, J. of Structural Eng. 134, 10 (2008)

12. M. Hosseini, P.S. Heidari, M. Heravi, Proc. of The $14^{\text {th }}$ World Conference on Earthquake Engineering 2008 (2008)

13. ASCE, Minimum Design Loads and Associated Criteria for Buildings and Other Structures ASCE/SEI 7-16 (American Society of Civil Engineers, Virginia, 2017)

14. Standar Nasional Indonesia, Tata Cara Perencanaan Ketahanan Gempa untuk Struktur Bangunan Gedung dan Non Gedung SNI 1726-2012 (Badan Standardisasi Nasional, Jakarta, 2015) 